\title{
Gambaran Pola Resistensi Bakteri di Unit Perawatan Neonatus
}

\author{
Pertin Sianturi, Beby S. Hasibuan, Bugis M. Lubis, Emil Azlin, Guslihan Dasa Tjipta \\ Departemen Ilmu Kesehatan Anak Fakultas Kedokteran Universitas Sumatera Utara/RSUP H Adam \\ Malik, Medan
}

\begin{abstract}
Latar belakang. Angka kejadian sepsis neonatus di negara sedang berkembang masih cukup tinggi. Sepsis neonatus paling sering disebabkan oleh infeksi bakteri. Penundaan pengobatan akan menyebabkan perburukan penyakit dan mengakibatkan kematian. Sebaliknya penanganan yang berlebihan akan meningkatkan penggunaan antibiotik, lama rawatan, dan kejadian infeksi nosokomial.

Tujuan. Untuk menentukan pola kuman dan resistensi antibiotik di unit perawatan neonatus RSUP. H Adam Malik Medan sebagai acuan pemilihan antibiotik.

Metode. Penelitian observasional deskriptif berdasarkan data rekam medik pasien dirawat di Unit Perawatan Neonatus RSUP.HAM sejak 1 Januari 2008 sampai 31 Desember 2010. Semua bayi dengan gejala klinis sepsis diberikan antibiotik empirik sampai hasil kultur diperoleh. Semua hasil biakan diuji kepekaan dan resistensi terhadap berbagai jenis antibiotik.

Hasil. Jumlah pasien rawatan 1403 orang dengan sangkaan sepsis 239 bayi. Hasil biakan darah yang diperoleh tahun 2008 sampai 2010 berturut-turut 43/66 kasus, 80/118 kasus, dan 35/55 kasus. Sepsis neonatus dominan laki-laki, yaitu 86 (54,4\%). Bayi prematur menderita sepsis 45(28,5\%). Kuman paling banyak dijumpai adalah kuman gram negatif. Kuman penyebab sepsis paling banyak adalah Staphylococcus $s p$ diikuti Pseudomonas $s p$ dan Enterobacter $s p$. Vancomycin merupakan antibiotik paling sensitif tahun 2008 dan 2009 sedangkan tahun 2010 antibiotik paling sensitif adalah amikacin. Resistensi kuman terhadap antibiotik golongan Penicillin sudah sangat tinggi. Bakteri staphylococcus sp, pseudomonas sp, enterobacter $s p$ masih sensitif terhadap antibiotik vankomisin, amikasin dan meropenem.

Kesimpulan. Pola kuman paling banyak dijumpai di unit perawatan neonatus RSUP.HAM adalah Staphylococcus sp, Pseudomonas sp dan Enterobacter sp sensitif terhadap vancomycin, meropenem dan amikacin sedangkan penggunaan antibiotik lini pertama yaitu ampisilin, gentamicin dan cefotaxime telah resisten.
\end{abstract}

Sari Pediatri 2012;13(6):431-6.

Kata kunci: Sepsis neonatus, pola kuman

\footnotetext{
Alamat korespondensi:

Dr. Pertin Sianturi, Sp.A. Staf Devisi Perinatology Departemen Ilmu Kesehatan Anak FK-USU/RSUP. H. Adam Malik Medan Jl. Bunga Lau No.17, Medan 20136. Telp. (061) 8365663. Fax. (061) 8361721. E-mail: pertin_sianturi2@yahoo.com
}

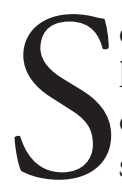
epsis pada neonatus merupakan suatu sindrom klinis penyakit infeksi yang disertai bakteremia dan terjadi pada bulan pertama kehidupan dan sampai saat ini masih merupakan masalah di bidang neonatologi. Berdasarkan data World Health 
Organization (WHO), terdapat 10 juta kematian neonatus dari 130 juta bayi yang lahir setiap tahunnya. ${ }^{1-3}$

Kesehatan neonatus merupakan agenda utama di negara-negara sedang berkembang. Secara global 5 juta neonatus meninggal setiap tahunnya, 98\% di antaranya terjadi di negara sedang berkembang. Angka kematian bayi $50 \%$ terjadi pada periode neonatus dan 50\% terjadi pada minggu pertama kehidupan. Penyebab langsung mortalitas pada neonatus adalah sepsis, asfiksia neonatorum, trauma lahir, prematuritas dan malformasi kongenital. Mayoritas kematian neonatus terjadi pada bayi berat lahir rendah (BBLR). Lebih dari sepertiga dari empat juta bayi meninggal di dunia setiap tahunnya yang disebabkan oleh infeksi berat dan $25 \%$ dari 1000 bayi yang meninggal disebabkan oleh karena sepsis neonatus. ${ }^{3-5}$

Angka kejadian sepsis pada neonatus di negara yang sedang berkembang masih cukup tinggi berkisar 18 kasus setiap 1000 kelahiran dibanding di negara maju berkisar 1 sampai 5 kasus setiap 1000 kelahiran. Pada bayi berat lahir amat sangat rendah (BBLASR), kejadian sepsis terjadi 26 kasus setiap 1000 kelahiran dan keadaan ini berbeda bermakna dengan bayi berat lahir antara 1000 sampai 2000 gram yang angka kejadian sepsis berkisar 8 sampai 9 kasus setiap 1000 kelahiran. Demikian juga risiko kematian pada BBLR lebih tinggi dibanding bayi cukup bulan. ${ }^{6,7}$

Penyebab sepsis pada neonatus paling sering disebabkan oleh infeksi bakteri tetapi infeksi virus juga tidak boleh diabaikan karena enterovirus dapat juga menyebabkan sepsis atau neonatal meningitis. ${ }^{8}$ Dari tahun ke tahun angka kejadian sepsis tidak banyak mengalami penurunan yang bermakna tapi tingkat kematian pada neonatus disebabkan sepsis menurun drastis, hal ini disebabkan karena kemajuan teknologi kedokteran serta penemuan berbagai macam antibiotik baru. ${ }^{9}$

Menegakkan diagnosis sepsis pada neonatus tidak mudah karena gejala dan tandanya tidak spesifik, dapat menyerupai keadaan lain yang disebabkan oleh non infeksi. ${ }^{10}$ Pembuktian adanya infeksi dengan biakan darah sering tidak memuaskan dan membutuhkan waktu yang lama. Penundaan pengobatan akan menyebabkan perburukan penyakit dan mengakibatkan kematian. Sebaliknya penanganan yang berlebihan akan meningkatkan penggunaan antibiotik, lama rawat inap, dan kejadian infeksi nosokomial. ${ }^{11,12}$ Apabila pola kuman dan resistensi belum diketahui maka akan sulit menentukan antibiotik lini pertama pada pasien tersangka sepsis sampai hasil kultur diperoleh, sehingga setiap unit perawatan neonatus harus mempunyai pola kuman dan resistensi sendiri.

\section{Metode}

Penelitian observasional deskriptif berdasarkan data rekam medik pasien yang dirawat di Unit Perawatan Neonatus RSUP H Adam Malik Medan sejak 1 Januari 2008 sampai dengan 31 Desember 2010. Semua bayi dengan gejala klinis sepsis (distres pernapasan, hipotermia, hipertermia, distensi abdomen, muntah, gangguan sirkulasi, letargi, dan lain-lain) diberikan antibiotik empirik (ampicillin dan gentamicin atau gentamicin dan cefotaxim) hingga hasil kultur diperoleh. Pemeriksaan kultur darah dilakukan sebelum dimulai pemberian antibiotik, dan pemeriksaan kultur diulang bila terjadi perburukan penyakit, tetapi akibat keterbatasan teknik pemeriksaan maka tidak jarang sampel darah diambil setelah pemberian antibiotik. Semua hasil kultur darah dilakukan uji kepekaan dan resistensi terhadap berbagai jenis antibiotik.

\section{Hasil}

Jumlah pasien rawatan 1403 orang (tahun 2008 yaitu 422 orang, tahun 2009 yaitu 522 orang, dan tahun 2010 yaitu 459 orang). Semua pasien dengan gejala klinis sepsis dilakukan pemeriksaan kultur darah. Hasil kultur darah yang diperoleh sejak tahun 2008 sampai 2010 berturut-turut $43 / 66(65,1 \%), 80 / 118(67,8 \%)$, dan 35/55 (63,6\%) kasus.

Kasus sepsis lebih dominan pada bayi laki-laki $86(54,4 \%)$. Bayi prematur yang menderita sepsis $45(28,5 \%)$. Usia rata- rata saat masuk rumah sakit $5,4 \pm 5,31$ hari. Kasus sepsis awitan dini 97(61,4\%), kelainan bawaan 69(43,7\%) kasus. Jumlah pasien sepsis meninggal 52(32,9\%) kasus (Tabel 1).

Kuman yang paling banyak dijumpai selama tiga tahun berturut-turut adalah kelompok gram negatif. Jenis kuman penyebab sepsis neonatus yang paling banyak adalah Staphylococcus sp diikuti kuman Pseudomonas sp dan Enterobactersp (Tabel 2).

Vancomycin merupakan antibiotik yang paling sensitif pada tahun 2008 dan 2009 sedangkan pada tahun 2010 antibiotik yang paling sensitif adalah amikacin (Tabel 3). 
Resistensi kuman terhadap antibiotik golongan Penicillin sudah sangat tinggi sedangkan golongan cefalosforin generasi III (cefotaxime, ceftriaxon) sebagai obat yang sering digunakan sebagai antibiotik lini kedua, resistensinya juga sudah tinggi (Tabel 4).

Kuman staphylococcus $s p$ masih sensitif terhadap antibiotik vancomycin dan amikacin. Kuman pseudomonas sp sensitif terhadap antibotik vancomycin dan meropenem. Kuman enterobacter sp masih sensitif terhadap antibiotik vancomycin, meropenem, amikacin. Kuman klebsiella sp sensitif terhadap antibiotik meropenem. Kuman streptococcus sp sensitif terhadap amikacin. (Tabel 5). Kuman Pseudomonas sp, Klebsiella sp, Enterobacter $s p$ resisten terhadap antibiotik lini pertama(Tabel 6).

Tabel 1. Karakteristik pasien neonatus dengan hasil biakan positif

\begin{tabular}{lcccc}
\hline Karakteristik & 2008 & 2009 & 2010 & Total \\
\hline Jenis kelamin, n (\%) & & & & \\
$\quad$ Laki-laki & $25(58,1)$ & $42(52,5)$ & $19(54,2)$ & $86(54.4)$ \\
$\quad$ Perempuan & $18(41,9)$ & $38(47,5)$ & $16(45,8)$ & $72(45,6)$ \\
Gestasi, n (\%) & & & & \\
$\quad$ Kurang bulan & $14(32,6)$ & $21(26,2)$ & $10(28,6)$ & $45(28,5)$ \\
$\quad$ Cukup/lewat bulan & $29(67,4)$ & $59(73,8)$ & $25(71,4)$ & $113(71,5)$ \\
Jenis persalinan, n (\%) & & & \\
$\quad$ Spontan & $21(48,9)$ & $53(66,2)$ & $16(45,7)$ & $90(56,0)$ \\
Vakum & 0 & $3(3.8)$ & $1(2,9)$ & $4(2,5)$ \\
Operasi & $22(51,1)$ & $24(30)$ & $18(51,4)$ & $64(40,5)$ \\
Umur rata-rata (hari), n & 5,1 & 6,2 & 5,1 & 5,4 \\
$\quad \pm$ SD & 5,46 & 6,12 & 4,36 & 5,31 \\
Usia klinis sepsis (jam) n(\%) & & & & \\
$\quad \leq 72$ & $32(74,4)$ & $47(58,8)$ & $18(51,4$ & $97(61,4)$ \\
$\quad>72$ & $11(25,6)$ & $33(41,2)$ & $17(48,6)$ & $61(38,6)$ \\
Kelainan kongenital, n (\%) & $14(32,5)$ & $39(48,8)$ & $16(45,7)$ & $69(43,7)$ \\
Outcome n (\%) & & & & \\
Pulang sembuh & $10(23,3)$ & $39(48,8)$ & $18(51,4)$ & $67(42,4)$ \\
$\quad$ Pulang paksa & $21(48,8)$ & $14(17,4)$ & $4(11,5)$ & $39(24,7)$ \\
$\quad$ Meninggal & 12 & 27 & $13(37,1)$ & $52(32,9)$ \\
\hline
\end{tabular}

Tabel 2. Pola bakteri pada pasien sepsis neonatus periode tahun 2008 - 2010

\begin{tabular}{lcccc}
\hline Jenis bakteri & 2008 & 2009 & 2010 & Total \\
& $\mathrm{n}(\%)$ & $\mathrm{n}(\%)$ & $\mathrm{n}(\%)$ & $\mathrm{n}$ \\
\hline Staphylococcus sp & $13(33)$ & $21(21)$ & $12(43)$ & 46 \\
S. aureus & $5(38)$ & $1(5)$ & $4(33)$ & 10 \\
S. epidermidis & $5(38)$ & $4(21)$ & $5(42)$ & 14 \\
Streptococcus sp & 0 & $9(11)$ & $2(5)$ & 11 \\
S. pneumonia & 0 & 0 & $1(1)$ & 1 \\
Klebsiella sp & $10(23)$ & $4(5)$ & $1(2)$ & 4 \\
K.pneumoniae & $4(40)$ & 0 & 0 & 27 \\
Pseudomonas sp & $9(20)$ & $13(10)$ & $5(14)$ & 6 \\
P. aeruginosa & $6(67)$ & 0 & 0 & 23 \\
Enterobacter sp & $4(4)$ & $14(18)$ & $5(5)$ & 7 \\
E. aerogenes & $1(25)$ & $2(2)$ & $5(100)$ & 4 \\
Proteus sp & $4(9)$ & $3(3)$ & 0 & 3 \\
Citrobacter sp & $1(2)$ & $3(3)$ & 0 & 4 \\
Eschericia coli & $1(2)$ & $2(2)$ & 0 & 3 \\
Salmonella typhi & $1(1)$ & $2(2)$ & $1(2)$ & 15 \\
Serretia sp & 0 & 0 & $3(3)$ & $6(17)$ \\
Lain-lain & 0 & $9(11)$ & & \\
\hline
\end{tabular}


Tabel 3. Pola kepekaan antibiotik pada pasien sepsis neonatus tahun 2008-2010

\begin{tabular}{lccccccc}
\hline \multirow{2}{*}{ Antibiotik } & $\begin{array}{c}\text { Biakan } \\
\text { sensitif }\end{array}$ & \multicolumn{2}{c}{ Tahun 2008} & \multicolumn{2}{c}{ Tahun 2009} & \multicolumn{2}{c}{ Tahun 2010} \\
& $\mathrm{n}$ & $\mathrm{n}$ & $\%$ & $\mathrm{n}$ & $\%$ & $\mathrm{n}$ & $\%$ \\
\hline Vancomycin & $22 / 27$ & $10 / 11$ & 90,9 & $7 / 8$ & 87,5 & $5 / 8$ & 62,5 \\
Meropenem & $61 / 80$ & $31 / 36$ & 86 & $19 / 29$ & 65,5 & $11 / 15$ & 73,3 \\
Amikacin & $89 / 126$ & $27 / 44$ & 61,4 & $35 / 49$ & 71,4 & $27 / 33$ & 81,8 \\
Amoxiclave & $47 / 102$ & $11 / 34$ & 32,3 & $19 / 41$ & 46,3 & $17 / 27$ & 62,9 \\
Cefoperazon & $27 / 78$ & $14 / 33$ & 42,4 & $10 / 26$ & 38,5 & $3 / 19$ & 15,8 \\
Tetracyclin & $39 / 124$ & $5 / 31$ & 16,1 & $22 / 59$ & 37,3 & $12 / 34$ & 35,3 \\
Erythromycin & $32 / 104$ & $3 / 17$ & 17,6 & $21 / 53$ & 39,6 & $8 / 34$ & 23,5 \\
Cloramphenicol & $19 / 71$ & $10 / 38$ & 26,3 & $0 / 12$ & 0 & $9 / 21$ & 42,8 \\
Cefepime & $10 / 45$ & $8 / 26$ & 30,8 & $0 / 12$ & 0 & $2 / 7$ & 28,6 \\
Cefotaxime & $18 / 98$ & $4 / 36$ & 11,1 & $8 / 39$ & 20,5 & $6 / 23$ & 26,1 \\
\hline
\end{tabular}

Tabel 4. Pola resistensi antibiotik pada pasien sepsis neonatus tahun $2008-2010$

\begin{tabular}{lccccccc}
\hline \multirow{2}{*}{ Antibiotik } & $\begin{array}{c}\text { Biakan } \\
\text { resisten }\end{array}$ & \multicolumn{2}{c}{ Tahun 2008} & \multicolumn{2}{c}{ Tahun 2009} & \multicolumn{2}{c}{ Tahun 2010} \\
& $\mathrm{n}$ & $\mathrm{n}$ & $\%$ & $\mathrm{n}$ & $\%$ & $\mathrm{n}$ & $\%$ \\
\hline Penicillin & $79 / 90$ & $12 / 13$ & 92,3 & $37 / 44$ & 84,1 & $30 / 33$ & 90,9 \\
Ampicillin & $91 / 128$ & $26 / 33$ & 78,8 & $40 / 60$ & 66,7 & $25 / 35$ & 71,5 \\
Ceftriaxon & $38 / 56$ & $29 / 38$ & 76,3 & $2 / 7$ & 28,6 & $7 / 11$ & 63,6 \\
Cefotaxime & $65 / 99$ & $28 / 37$ & 75,7 & $24 / 39$ & 61,5 & $13 / 23$ & 56,5 \\
Cloramfenicol & $46 / 71$ & $24 / 38$ & 63,2 & $12 / 12$ & 100 & $10 / 21$ & 47,6 \\
Gentamicin & $75 / 117$ & $31 / 41$ & 75,6 & $28 / 46$ & 60,9 & $16 / 30$ & 53,3 \\
Cefepime & $25 / 45$ & $11 / 26$ & 42,3 & $10 / 12$ & 83,3 & $4 / 7$ & 57,1 \\
Erythromycin & $57 / 104$ & $13 / 17$ & 76,4 & $28 / 53$ & 52,8 & $16 / 34$ & 47 \\
Tetracyclin & $64 / 124$ & $23 / 31$ & 74,2 & $24 / 59$ & 40,7 & $17 / 34$ & 50 \\
Cefoperazon & $32 / 78$ & $11 / 33$ & 33,3 & $11 / 26$ & 42,3 & $10 / 19$ & 52,6 \\
\hline
\end{tabular}

Tabel 5. Pola kepekaan antibiotik terhadap bakteri penyebab sepsis

\begin{tabular}{|c|c|c|c|c|c|c|c|c|c|c|}
\hline \multirow{3}{*}{ Antibiotik } & \multicolumn{2}{|c|}{$\begin{array}{l}\text { Staphylo- } \\
\text { coccus sp }\end{array}$} & \multicolumn{2}{|c|}{$\begin{array}{l}\text { Pseudo- } \\
\text { monas sp }\end{array}$} & \multicolumn{2}{|c|}{$\begin{array}{c}\text { Entero-bacter } \\
s p\end{array}$} & \multicolumn{2}{|c|}{ Klebsiella sp } & \multicolumn{2}{|c|}{$\begin{array}{l}\text { Strepto- } \\
\text { coccus sp }\end{array}$} \\
\hline & S & $\mathrm{R}$ & $S$ & $\mathrm{R}$ & $S$ & $\mathrm{R}$ & $S$ & $\mathrm{R}$ & $S$ & $\mathrm{R}$ \\
\hline & $\%$ & $\%$ & $\%$ & $\%$ & $\%$ & $\%$ & $\%$ & $\%$ & $\%$ & $\%$ \\
\hline \multirow[t]{2}{*}{ Vancomycin } & 20 & 1 & 0 & 1 & 0 & 3 & 0 & 0 & 2 & 2 \\
\hline & 95 & 5 & 0 & 100 & 0 & 100 & 0 & 0 & 50 & 50 \\
\hline \multirow[t]{2}{*}{ Meropenem } & 20 & 11 & 16 & 2 & 14 & 0 & 12 & 3 & 3 & 1 \\
\hline & 61 & 33 & 80 & 10 & 100 & 0 & 80 & 20 & 75 & 25 \\
\hline \multirow[t]{2}{*}{ Amikacin } & 34 & 1 & 12 & 3 & 21 & 1 & 10 & 2 & 9 & 1 \\
\hline & 85 & 3 & 52 & 13 & 81 & 4 & 71 & 14 & 90 & 10 \\
\hline \multirow[t]{2}{*}{ Amoxiclav } & 20 & 8 & 5 & 5 & 8 & 7 & 3 & 6 & 4 & 2 \\
\hline & 65 & 26 & 31 & 31 & 40 & 35 & 30 & 60 & 50 & 25 \\
\hline \multirow[t]{2}{*}{ Cefoperazon } & 14 & 9 & 6 & 9 & 2 & 7 & 4 & 3 & 3 & 4 \\
\hline & 48 & 31 & 32 & 47 & 20 & 70 & 40 & 30 & 43 & 57 \\
\hline
\end{tabular}


Tabel 6. Resistensi antibiotik terahadap bakteri penyebab sepsis

\begin{tabular}{|c|c|c|c|c|c|c|c|c|c|c|}
\hline \multirow{3}{*}{ Antibiotik } & \multicolumn{2}{|c|}{$\begin{array}{l}\text { Staphylo- } \\
\text { coccus sp }\end{array}$} & \multicolumn{2}{|c|}{$\begin{array}{l}\text { Pseudo- } \\
\text { monas sp }\end{array}$} & \multicolumn{2}{|c|}{$\begin{array}{c}\text { Entero- } \\
\text { bacter sp }\end{array}$} & \multicolumn{2}{|c|}{$\begin{array}{l}\text { Klebsiella } \\
\text { sp }\end{array}$} & \multicolumn{2}{|c|}{$\begin{array}{l}\text { Strepto- } \\
\text { coccus sp }\end{array}$} \\
\hline & $S$ & $\mathrm{R}$ & $S$ & $\mathrm{R}$ & $S$ & $\mathrm{R}$ & $S$ & $\mathrm{R}$ & $S$ & $\mathrm{R}$ \\
\hline & $\%$ & $\%$ & $\%$ & $\%$ & $\%$ & $\%$ & $\%$ & $\%$ & $\%$ & $\%$ \\
\hline \multirow[t]{2}{*}{ Ampicillin } & 14 & 19 & 1 & 21 & 0 & 23 & 0 & 8 & 6 & 7 \\
\hline & 35 & 48 & 4 & 84 & 0 & 100 & 0 & 89 & 40 & 47 \\
\hline \multirow[t]{2}{*}{ Ceftriaxone } & 5 & 10 & 2 & 6 & 0 & 7 & 0 & 7 & 2 & 0 \\
\hline & 33 & 67 & 17 & 50 & 0 & 100 & 0 & 100 & 100 & 0 \\
\hline \multirow[t]{2}{*}{ Cefotaxime } & 11 & 13 & 1 & 11 & 1 & 16 & 1 & 8 & 3 & 1 \\
\hline & 37 & 43 & 6 & 69 & 6 & 89 & 11 & 89 & 50 & 17 \\
\hline \multirow{2}{*}{ Cloramfenicol } & 6 & 14 & 3 & 6 & 3 & 6 & 3 & 5 & 2 & 4 \\
\hline & 27 & 64 & 30 & 60 & 30 & 60 & 30 & 50 & 33 & 67 \\
\hline \multirow[t]{2}{*}{ Gentamicin } & 6 & 20 & 4 & 12 & 1 & 17 & 1 & 10 & 3 & 3 \\
\hline & 17 & 57 & 18 & 54 & 4 & 65 & 9 & 91 & 43 & 43 \\
\hline
\end{tabular}

\section{Pembahasan}

Sepsis neonatus masih merupakan masalah dalam pelayanan dan perawatan neonatus. Di negara sedang berkembang sebagian besar bayi yang dirawat di ruang perawatan mempunyai kaitan dengan masalah sepsis. Tingkat mortalitas sepsis neonatus di negara maju pada periode 1979 - 1994 sebesar 21\%.7 Menurut data dari Survei Demografi dan Kesehatan Indonesia (SDKI) pada tahun 2007, angka kematian neonatal di Indonesia sebesar 19 kematian per 1000 kelahiran hidup. Penyebab kematian terbanyak pada usia 0-6 hari adalah gangguan pernafasan $(37 \%)$, prematuritas (34\%), dan sepsis (12\%). ${ }^{13}$ Angka kematian akibat sepsis neonatus di RS Haji Adam Malik pada periode tahun 2008 - 2010 sebesar 32,9\%. Hampir semua bayi yang terdiagnosis sepsis neonatus merupakan pasien rujukan dengan usia rata-rata 5,4 hari sedangkan gejala sepsis telah timbul lebih banyak pada usia $\leq 72$ jam. Selain itu antibiotik yang digunakan sebagai lini pertama ternyata sudah resisten dan hasil kultur darah diperoleh setelah $6,2 \pm 1,48$ hari.

Pola kuman pada sepsis awitan dini cenderung berubah setiap waktu. Sebelum tahun 1965, staphylococcus aureus dan escherechia coli merupakan kuman yang sering ditemukan pada kultur. Pada akhir 1960-an, grup B streptococcus (GBS) merupakan kuman terbanyak. Sekarang, kebanyakan rumah sakit masih melaporkan GBS sebagai kuman terbanyak penyebab sepsis walaupun insiden di negara maju cenderung turun setelah dilakukan penapisan neonatal terhadap kolonisasi GBS pada usia gestasi 35 sampai
37 minggu dan profilaksis antibiotik pada ibu hamil yang ditemukan kolonisasi. Sejak tahun 1980, kuman Staphylococcus epidermidis mulai menimbulkan masalah di unit perawatan intensif neonatus. ${ }^{14,15}$

Kuman penyebab sepsis di unit perawatan neonatus Rumah Sakit Haji Adam Malik Medan (RSHAM) yang paling banyak selama 3 tahun berturut-turut adalah adalah staphylococcus sp, Pseudomonas sp, Enterobacter sp tetapi tidak berhasil diidentifikasi apakah kuman tersebut merupakan penyebab sepsis awitan dini atau lambat. Kuman E.coli teridentifikasi hanya 3 spesimen selama 3 tahun, hal ini mungkin terjadi kerena pemakaian antibiotik empirik sudah mulai diberikan sebelum sampel darah diambil.

Kuman penyebab sepsis awitan lambat atau sepsis nosokomial berbeda pada tiap unit perawatan neonatal, tetapi coagulase-negative Staphylococci (CoNS), terutama Staphylococcus epidermidis. Mikroorganisme lain termasuk Pseudomonas, Klebsiella, Serratia, dan Proteus. ${ }^{14,15}$ Jenis kuman yang sama, kecuali CoNS ditemukan juga di unit perawatan neonatus RSHAM yang merupakan kuman yang sering ditemukan pada sepsis awitan lambat atau sepsis nosokomial.

Pengobatan sepsis neonatus telah dimulai sebelum kuman penyebab yang pasti diidentifikasi. Biasanya dimulai dengan golongan penisilin, seperti ampisilin digabung dengan golongan aminoglikosida seperti gentamisin. Pada sepsis nosokomial, kuman di NICU harus dipertimbangkan, secara umum staphylococcal dapat diatasi dengan vancomycin digabung dengan 
aminoglikosida seperti gentamicin atau amikacin. ${ }^{7}$ Berdasarkan kepekaan kuman di unit perawatan neonatus RSHAM, ampisilin, gentamisin dan cefotaxime sudah resisten. Kepekaan antibiotik vancomycin, meropenem dan amikacin masih cukup tinggi.

Hasil penelitian ini merupakan dasar pemikiran pihak terkait untuk membuat kebijakan pemilihan antibiotik sebagai pengobatan lini pertama sepsis neonatus sebelum hasil kultur darah diperoleh. Hasil kultur darah diharapkan dapat diperoleh dalam waktu 3 hari sebagai dasar pemilihan antibiotik selanjutnya.

\section{Kesimpulan}

Pola kuman yang paling banyak dijumpai di unit perawatan neonatus RSHAM adalah Staphylococcus $s p$, Pseudomonas $s p$ dan Enterobacter $s p$ yang sensitif terhadap vancomycin, meropenem dan amikacine sedangkan penggunaan antibiotik lini pertama yaitu ampicillin, gentamicin dan cefotaxime telah resisten.

\section{Daftar pustaka}

1. Bone RC, Grodzin CJ, Balk RA. Sepsis: a new hypothesis for pathogenesis of the disease process. Chest 1997; 112:235-43

2. Gomella TL, Cunningham MD, Eyal FG, Zenk KE. Infectious disease. Dalam: Gomella TL, Cunningham MD, Eyal FG, Zenk KE, penyunting. Neonatology: Management, procedures, on-call problems, disease and drugs. Edisi ke-5. New York: Mc Graw-Hill; 2004. h. $434-40$

3. World Health Organization. Neonatal and perinatal mortality: country, regional and global estimates. Geneva Switzerland, World Health Organization, 2000.h.127

4. Alzahrani AJ, Hassan MI, Obeid EO, Diab AE, Qutub HO, Gupta RK. Rapid detection of procalcitonin as an early marker of sepsis in intensive care unit in tertiary hospital. Int J. Med Med. Sci 2009; 11:516-22

5. Hoffman DJ, Harris MC. Diagnosis of neonatal sepsis. Dalam: Spitzer AR, penyunting. Intensive care of the fetus and neonate. Philadelphia: Mosby Elsevier; 1996. h.940-50

6. Dear P. Infection in the newborn. Dalam: Rennie JM, penyunting. Roberton's textbook of neonatology. Edisi ke-4. USA: Elsevier Churchill Livingstone; 2005. h. 1011-92

7. Polin RA, Parravicini E, Regan JA, Taeusch HW. Bacterial sepsis and meningitis. Dalam: Taeusch HW, Ballard RA, Gleason CA, penyunting. Avery's diseases of the newborn. Edisi ke 8. Philadelphia: Elsevier Saunders; 2004. h.551-600

8. Clark R, Powers R, White R, Bloom B, Sanchez P, Benjamin DK. Nosocomial infection in the NICU: a medical complication or unavoidable problem?. J Perinatol 2004; 24:382-88

9. Hotchkiss RS, Karl IE. The pathophysiology and treatment of sepsis. N Engl J Med 2003; 348:138-50

10. Jumah DS, Hassan MK. Predictors of mortality outcome in neonatal sepsis. The Med J Bashrah University 2007; 25:11-8

11. Rohsiswatmo R. Kontroversi diagnosis sepsis neonatus. Dalam:Hegar B, Trihono PP, Ifran EB, penyunting. Update in neonatal Infections. Jakarta. Departemen Ilmu Kesehatan Anak Fakultas Kedokteran Universitas Indonesia; 2005. h.32-43

12. Fowlie PW, Schmidt B. Diagnostic test for bacterial infection from birth to 90 days-asystematic review. Arch Dis Child Fetal Neonatal Ed 1998; 78:F92-8

13. Kementrian Kesehatan RI. Survei demografi dan kesehatan Indonesia (SDKI) 2007

14. Darmstadt GL, Zaidi AK, Stoll BJ. Neonatal Infections: A Global Perspective. Dalam: Remington JS, Klein JO, Wilson CB, Nizet V, Maldonado YA, penyunting. Infectious Diseases of the fetus and newborn infant. Edisi ketujuh. Philadelphia: Elsevier sounders; 2011. h.24-51

15. Nizet V, Klein JO. Bacterial sepsis and Meningitis. Dalam: Remington JS, Klein JO, Wilson CB, Nizet V, Maldonado YA, penyunting. Infectious Diseases of the fetus and newborn infant. Edisi ketujuh. Philadelphia: Elsevier sounders; 2011. h.222-75 